Old Dominion University

ODU Digital Commons

1983

\title{
Cape Romain and the Charleston Bump: Historical and Recent Hydrographic Observations
}

\author{
J.J. Singer \\ L. P. Atkinson \\ Old Dominion University, latkinso@odu.edu
}

J. O. Blanton

J. A. Yoder

Follow this and additional works at: https://digitalcommons.odu.edu/ccpo_pubs

Part of the Oceanography Commons

\section{Original Publication Citation}

Singer, J. J., Atkinson, L. P., Blanton, J. O., \& Yoder, J. A. (1983). Cape Romain and the Charleston Bump: Historical and recent hydrographic observations. Journal of Geophysical Research: Oceans, 88(C8), 4685-4697. doi:10.1029/JC088iC08p04685| 


\title{
Cape Romain and the Charleston Bump: Historical and Recent Hydrographic Observations
}

\author{
J. J. SINGER \\ Science Applications, Inc., Raleigh, North Carolina 27606 \\ L. P. Atkinson, J. O. Blanton, and J. A. Yoder \\ Skidaway Institute of Oceanography, Savannah, Georgia 31406
}

\begin{abstract}
A review and analysis of historical and new hydrographic data are presented for the Charleston Bump region. An area of doming isotherms is identified primarily between $31.5^{\circ}$ and $34.5^{\circ} \mathrm{N}$ and the 200 and $400 \mathrm{~m}$ isobaths. The highest incidences of doming are found off Long Bay (86\%), Cape Fear (38\%), and Cape Romain (25\%). Evidence suggests that low salinity shelf water collects in the doming area off Long Bay in July and that seasonal fluctuations in the depth of the main thermocline layer in this area are linked to Gulf Stream transport and local winds. At times there is a gradual offshore-onshore movement of the Gulf Stream opposite Long Bay roughly following the $400 \mathrm{~m}$ isobath and at other times an abrupt eastward movement near $32^{\circ} \mathrm{N}$. Much of the time there appears to be a direct seasonal relationship between historical seasonal velocity fields and offshore deflection with higher (lower) velocities corresponding to greater (lesser) deflection.
\end{abstract}

\section{INTRODUCTION}

Recently, there has been a growing interest in the study of the seaward deflection of the Gulf Stream off Charleston, South Carolina. This interest has been fueled significantly by the advent of satellite infrared imagery. Rao et al. [1971] and DeRycke and Rao [1973] presented the first of this type data for the region, noting the recurring meander and eddy features. They suggested these were transient phenomena $\because$. . caused either by any one or a combination of factors like... strong northwest winds. . .bottom topography, and. . . baroclinic instability associated with the Gulf Stream boundary.' Legeckis [1976], using satellite imagery, again tied the phenomenon to the bathymetry (see Figure 1). However, the suggestion of a bathymetric influence was perhaps first implied by Bache in Pillsbury [1891], where he reported that observations off Charleston suggested some effect on the Gulf Stream due to '... the shape of the bottom of the sea.'

Through the years, many periodic observations have been made of the excursions of the Gulf Stream in the area. Bartlett [1883] and Pillsbury [1891] both noted an eastward flow of the Gulf Stream from surface drift measurements taken in the region. Fuglister and Worthington [1951] showed an eastward trend of the $100 \mathrm{~m}$ temperature front near $33^{\circ} \mathrm{N}$, Von Arx et al. [1955] observed an east to northeast trend in the surface frontal outcrop near $32^{\circ} \mathrm{N}$, and Pratt [1963] observed eastward flow in the bottom current. Schroeder [1963], Fuglister and Voorhis [1965], and Pratt [1966] all showed the offshore deflection in the $200 \mathrm{~m}$ contour of the $15^{\circ} \mathrm{C}$ isotherm, and Ewing et al. [1966] found that 'a major erosion channel cut(s) across the southward extension of the Cape Fear arch at about $32^{\circ} \mathrm{N} 78^{\circ} \mathrm{W} . .$. , Busby [1969] reported the entrainment of a deep-sea submersible in an eddy, and Knauss [1969] noted the apparent

Copyright 1983 by the American Geophysical Union.

Paper number $3 \mathrm{C} 0346$.

0148-0227/83/003C-0346\$05.00 occurrence of a large meander. Richardson et al. [1969], showed the Gulf Stream's high velocity core well offshore of the $200 \mathrm{~m}$ isobath just north of this area, and Pashinski and Maul [1973] stated that on one occasion the Gulf Stream had been observed to flow eastward as far as $76.5^{\circ} \mathrm{W}$ before turning northward.

More recently, the quasi-permanence of the deflection of the Gulf Stream surface thermal front has been documented for this area from Very High Resolution Radiometer (VHRR) and Radar Altimeter (RA) satellite data [Brooks and Bane, 1978; Pietrafesa et al., 1978; Legeckis, 1979]. In addition, at least two models have now been applied to the region examining bottom topography as an explanation for the feature [Rooney et al., 1978; Chao and Janowitz, 1979].

In studying this region, it is pointed out that satellite IR imagery is presently incapable of year-round monitoring because of periodic cloud cover and a negligible temperature gradient during the summer [Maul et al., 1978; Pietrafesa et al., 1978; Legeckis, 1979]. This is further emphasized by Strack's [1953] observation that June-October are the worst months for using sea surface temperature gradients as Gulf Stream indicators. Subsequently, there are distinct advantages of subsurface hydrographic data over satellite imagery.

Substantial hydrographic data sets have been collected in the area by numerous investigators. They are discussed in Bane [1983], Bane et al. [1980b, 1981], Vukovich and Crissman [1980], Mathews and Pashuk [1977], and Hazelworth [1976]. Earlier, the Gill cruises of 1953 and 1954 also sampled this region in considerable detail. Other investigators including Pierce [1953] and Costin [1969] have also periodically sampled the region.

The purpose of this paper is to review and examine these and other historical hydrographic data and to present new data for the 'Bump' region. It is the authors' view that this will serve as a foundation for future work in the area. A region of doming isotherms will be identified, and the seasonal characteristics of the region will be discussed. Onshore-offshore sections of temperature, salinity, nitrate, and total chlorophyll will be presented as well as a discus- 


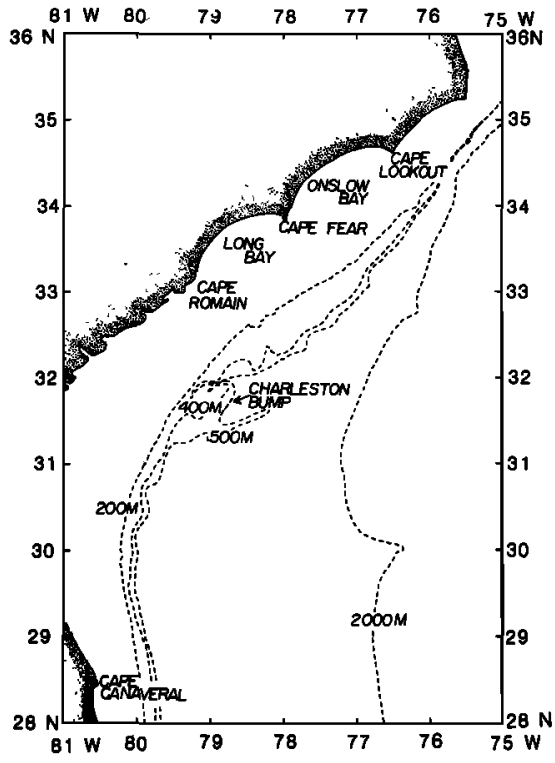

Fig. 1. Bathymetry of the South Atlantic Bight (SAB) and the study area [from American Association of Petroleum Geologists, 1970].

sion of the characteristics of Gulf Stream deflection off Long Bay.

\section{METHODS}

The historical data discussed in this paper are taken from technical publications that describe the respective sampling techniques and analytical methods. Data from the NOAA Peirce [Hazelworth, 1976] and R. V. Dolphin [Mathews and Pashuk, 1977] cruises were obtained from the National Oceanographic Data Center (NODC) on magnetic tape and were processed at Skidaway Institute of Oceanography (SKIO).

A Grundy model 9400 conductivity-temperature-depth (CTD) recorder, a General Oceanics model 1015 Rosette with Niskin bottles, and an expendable bathythermograph (XBT) were used on the authors' cruises. CTD data were processed according to Chandler et al. [1978] and XBT data were manually digitized. Nutrient samples were frozen in $125 \mathrm{ml}$ polyethylene bottles and stored in the dark until thawed and analyzed on shore. Standard Technicon Autoanalyzer methods were used [Glibert and Loder, 1977]. Duplicate chlorophyll samples were filtered and frozen and stored in the dark. Total chlorophyll was determined by the method of Yentsch and Menzel [1963] as described by Strickland and Parsons [1972].

\section{Doming Region}

Vertically, hydrographic data in the region opposite Long and Onslow Bays (Figure 1) are often characterized by doming (an upward and downward bending) of the isopleths in the area between the shelf break and the Gulf Stream. For the purpose of this paper, this phenomenon (probably associated with a cyclonic flow pattern) is defined for a crossshelf section as an upward and then downward sloping of the $15^{\circ} \mathrm{C}$ isotherm in the upper layer $(0-200 \mathrm{~m})$ offshore of the $200 \mathrm{~m}$ isobath (Figure $2 a$ ). This definition distinguishes the phenomenon from upwelling that may occur along the shelf break (Figure $2 b$ ) and most frontal eddies [Lee et al., 1981] observed south of $31.5^{\circ} \mathrm{N}$. The $15^{\circ} \mathrm{C}$ dome of these latter features is generally shoreward of the $200 \mathrm{~m}$ isobath and much less broad. No attempt is made to distinguish between doming associated with an apparent quasi-permanent meander opposite Long Bay and that observed further downstream (NE) associated with larger frontal eddies that occur with 2 to 14 day periods.

In examining the available data (Tables 1, 2, and 3), it was noted that in some instances only an upward sloping was observed as the sampling did not extend far enough offshore to detect the eastern extent of the dome. In such cases, the location of the furthest sample offshore from the $200 \mathrm{~m}$ isobath was considered the maximum dome (inflection or center) position. Further, in most instances at least two stations offshore of the $200 \mathrm{~m}$ isobath were necessary in order to apply the above definition. When two such stations were not available, a careful examination was made of the contours at shallower depths. This eliminated some sections that otherwise appeared applicable.

\section{Doming Statistics}

A region of maximum doming was identified between $31.5^{\circ}$ and $34.5^{\circ} \mathrm{N}$ (Figure 3; sub-regions II, III, and IV). This corresponds to the same region where the Gulf Stream surface thermal front has been observed to move offshore and then back onshore by Bane and Brooks [1979] and where subsurface temperature data $\left(15^{\circ} \mathrm{C}\right.$ at $\left.200 \mathrm{~m}\right)$ reported by Bane et al. [1980a, b, 1981], Bane and Brooks [1981], Pratt [1966], Fuglister and Voorhis [1965], and Schroeder [1963] all show the same trends. It is also the region over which the $400 \mathrm{~m}$ isobath has been observed to diverge from and return toward the $200 \mathrm{~m}$ isobath.

Nearly $75 \%$ of all doming observations occurred in the area between the 200 and $400 \mathrm{~m}$ isobaths. However, doming was also observed offshore of the $500 \mathrm{~m}$ isobath, particularly north of $33^{\circ} \mathrm{N}$ where the continental slope steepens. The average water depth at the center dome position was $360 \mathrm{~m}$ for all data and $310 \mathrm{~m}$ for the observations occurring between the 200 and $400 \mathrm{~m}$ isobaths.

South of $31.5^{\circ} \mathrm{N}$, a few doming events were observed in region I. These were related to frontal eddies with the exception of the event at $30.8^{\circ} \mathrm{N}$ where a Gulf Stream meander was identified. The events in region IV are also thought to be attributable to the periodic occurrence of frontal eddies though much farther offshore. Region II leads into the region of the quasi-permanent meander, and region III is opposite the meander. No particular significance should be inferred from the locations indicated as subregional barriers. They are only intended as estimates.

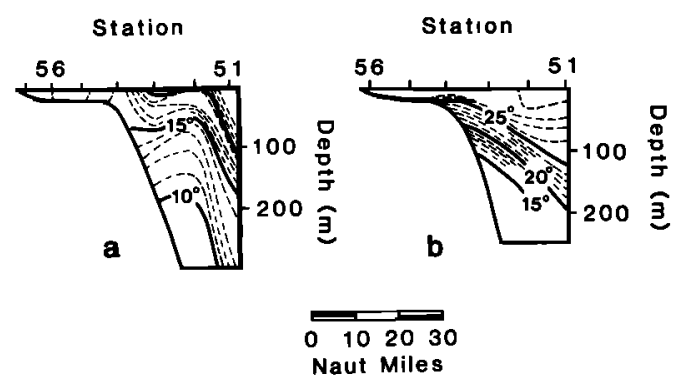

Fig. 2. (a) Doming and (b) upwelling at the shelf break off Long Bay, North Carolina [from Anderson et al., 1956a; Anderson and Gehringer, 1957a]. 
TABLE 1. Published Data Sources Examined in Compiling the Region of Maximum Doming

\begin{tabular}{|c|c|c|}
\hline Ship & Year & References for Vertical Plots of Temperature \\
\hline $\begin{array}{l}\text { Caryn and } A t- \\
\quad \text { lantis }\end{array}$ & $1953-1954$ & Bumpus and Pierce [1955] \\
\hline Gill & $1953-1954$ & $\begin{array}{c}\text { Anderson et al. }[1956 a, b] \text { and Anderson and } \\
\text { Gehringer }[1957 a, b, 1958,1959 a, b, c]\end{array}$ \\
\hline Atlantis & 1955 & Swallow and Worthington [1961] \\
\hline Peirce (NOAA) & $1965-1966$ & Hazelworth [1976] \\
\hline Eastward & $1966-1967$ & Stefánsson et al. [1971] \\
\hline Dolphin & 1973 & Mathews and Pashuk [1977] \\
\hline Eastward & $1973-1974$ & Atkinson [1978] \\
\hline Iselin & 1976 & Deschamps et al. [1979] \\
\hline Iselin & 1977 & Atkinson et al. [1979] \\
\hline $\begin{array}{l}\text { Advance II and } \\
\text { Blue Fin }\end{array}$ & 1977 & O'Malley et al. [1978] \\
\hline Northstar & 1977 & Vukovich and Crissman [1980] \\
\hline John de Wolf II & $1977-1978$ & Curtin $[1979 a, b, c, d]$ \\
\hline $\begin{array}{l}\text { Blue Fin and } \\
\text { Iselin }\end{array}$ & $1977-1978$ & Singer et al. $[1980]$ \\
\hline Iselin & 1978 & Lasley et al. [1979] \\
\hline AXBT's* & 1979 & Bane et al. $[1980 a]$ \\
\hline AXBT's* & 1979 & Bane and Brooks [1981] \\
\hline Endeavor & 1979 & Bane et al. [1980] \\
\hline Endeavor & 1979 & Brooks et al. [1980] \\
\hline Gillis & 1979 & Lasley et al. [1981] \\
\hline
\end{tabular}

*Airborne XBT's dropped.

\section{Relative Frequency}

The relative frequency of doming off Cape Romain, Long Bay, Cape Fear, and Onslow Bay was inferred from the Gill cruises (two cruises in each season) run along these sections (Figure 4; sections B, D, F, and G, respectively). The Gill cruises constitute the largest data set of seasonal repetitions of identical sections available. Doming occurred most frequently off Long Bay (six of seven times, 86\%) and to a lesser extent off Cape Romain (two of eight times, 25\%) and Cape Fear (three of eight times, 38\%). No doming observations were made on nine sections (not shown) that extended south to $27^{\circ} \mathrm{N}$, and only Onslow Bay (one of six times, 17\%) exhibited any doming on two northerly sections to Cape Lookout. Only in August 1953 (Gill cruise 3) did all four sections show no evidence of doming.

The higher incidence of doming off Long Bay tends to support the view of Pietrafesa and Janowitz [1980] and Pietrafesa [1983] that there is a cyclonic circulation pattern persisting throughout much of the year in this area. Such a circulation would be independent of the passage of frontal eddies, though perhaps modified by their occurrence or

TABLE 2. Seasonal Cruises by the Authors

\begin{tabular}{lll}
\hline \multicolumn{1}{c}{ Ship } & \multicolumn{1}{c}{$\begin{array}{c}\text { NODC } \\
\text { Identification }\end{array}$} & \multicolumn{1}{c}{ Dates } \\
\hline Pierce (Tracor) & PP-001-78 & March 6-12, 1978 \\
Iselin & IC-004-78 & April 12-23, 1978 \\
Iselin & IC-006-78 & July 26-30, 1978 \\
Iselin & IC-008-78 & Nov. 9-14, 1978 \\
Pierce (Tracor) & PP-001-79 & March 14-19, 1979 \\
Pierce (Tracor) & PP-002-79 & May 28 to June 2, 1979 \\
Pierce (Tracor) & PP-003-79 & Aug. 22-27, 1979 \\
Iselin & IC-002-79 & Oct. 27 to Nov. 2, 1979 \\
Eastward* & EZ-002-80 & April 10-27, 1980 \\
Iselin* & IC-003-80 & April 10-26, 1980 \\
Pierce (Tracor) & PP-001-80 & Sept. 3-14, 1980 \\
\hline
\end{tabular}

Data presented in unpublished reports.

${ }^{*}$ Cruise did not extend into the shelf break region north of $31.5^{\circ} \mathrm{N}$. enhanced by NE winds, which would strengthen southward flow along the western side of the dome. The lower incidence of doming events further downstream (NE) from Long Bay supports the view that they are caused there by the occasional appearance of frontal eddies well offshore of the $200 \mathrm{~m}$ isobath.

Seasonal Variations in Temperature, Salinity, and Sigma $T$ in the Doming Region Off Cape Romain

Twenty-five biweekly NOAA cruises from 1965 to 1966 [Hazelworth, 1976] present an excellent opportunity to examine the seasonal characteristics of the doming region off Cape Romain. The cruise track for this work is shown in Figure 4, section A. This section occurs rather close to and traverses southeastward across $32^{\circ} \mathrm{N} 79^{\circ} \mathrm{W}$, the location at which Brooks and Bane [1978], Pietrafesa et al. [1978], and Legeckis [1979] reported repeated seaward deflection of the surface thermal front from the $200 \mathrm{~m}$ isobath. Station spacing was approximately 10 nautical miles $(18.5 \mathrm{~km})$. These data reveal that the Gulf Stream was always east of station 4 and that the lowest temperatures at $200 \mathrm{~m}$ depth occurred at stations 3 or 4 of the data set in 316 and $403 \mathrm{~m}$ of water, respectively (Figure 4). The lower station temperatures at

TABLE 3. NODC Ship of Opportunity XBT Data and Plots Examined in Compiling the Region of Maximum Doming

\begin{tabular}{ccc}
\hline $\begin{array}{c}\text { NODC } \\
\text { Identification }\end{array}$ & $\begin{array}{c}\text { Originator's } \\
\text { Identification }\end{array}$ & Ship \\
\hline 50203 & 7611 & Lash Turkiye \\
51303 & 7703 & Lash Turkiye \\
51390 & 7704 & Mormac Argo \\
52342 & 7712 & Mormac Argo \\
52990 & 7810 & Lash Atlantico \\
52994 & 7811 & Lash Atlantico \\
\hline
\end{tabular}

An attempt was made to include naval XBT data; however, these efforts were unsuccessful as the data were not made available in a usable format. 


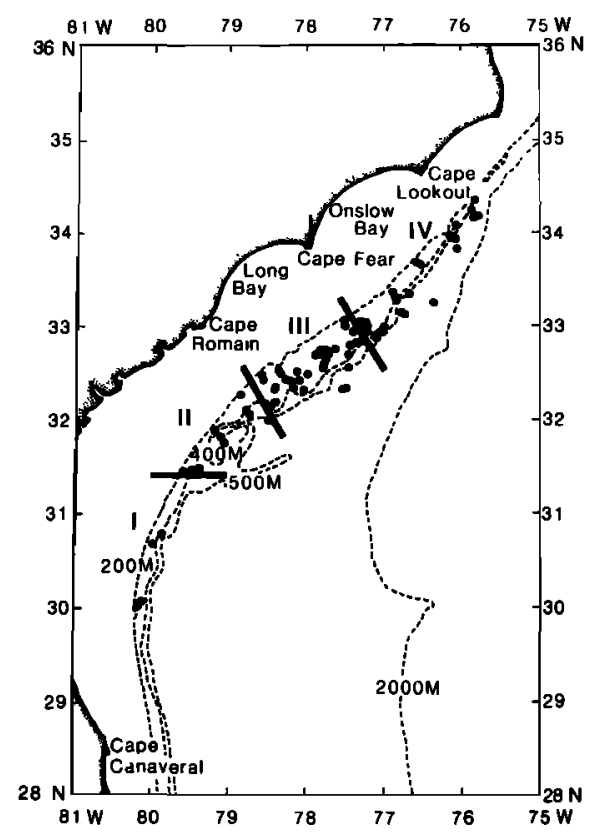

Fig. 3. Region of maximum doming. See text for discussion of sub-regions I-IV.

this depth and corresponding salinities and densities are plotted versus time in Figure 5. Also presented are the corresponding surface and $100 \mathrm{~m}$ observations.

\section{Surface Observations}

In the surface layer, high temperatures corresponded to low densities, and vice versa. There was no obvious relation to salinity. The highest temperatures occurred in late August and early September and the lowest in early February. The lowest surface salinities occurred primarily between late June and early August (during a period of extended southwesterly winds) with a secondary low in mid-May. The highest surface salinities were observed in December, January, February, and April.

The temperature and sigma $t$ observations are readily

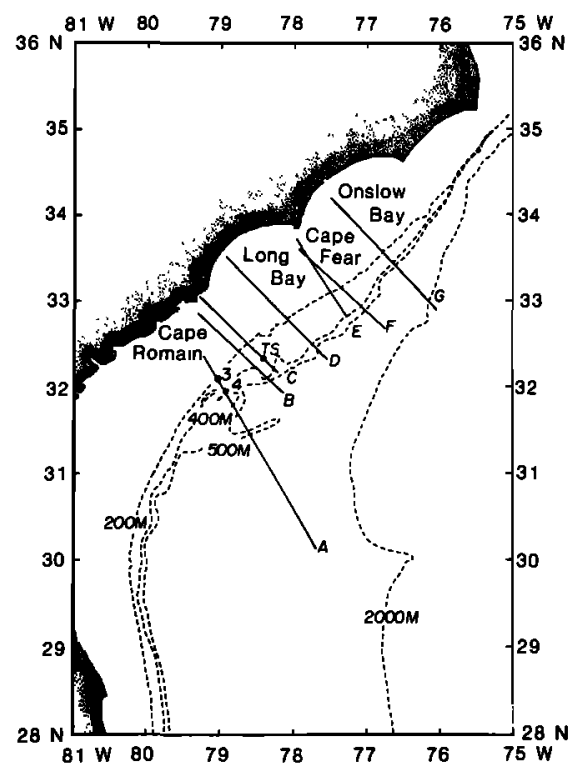

Fig. 4. Selected hydrographic sections A-G (see text).
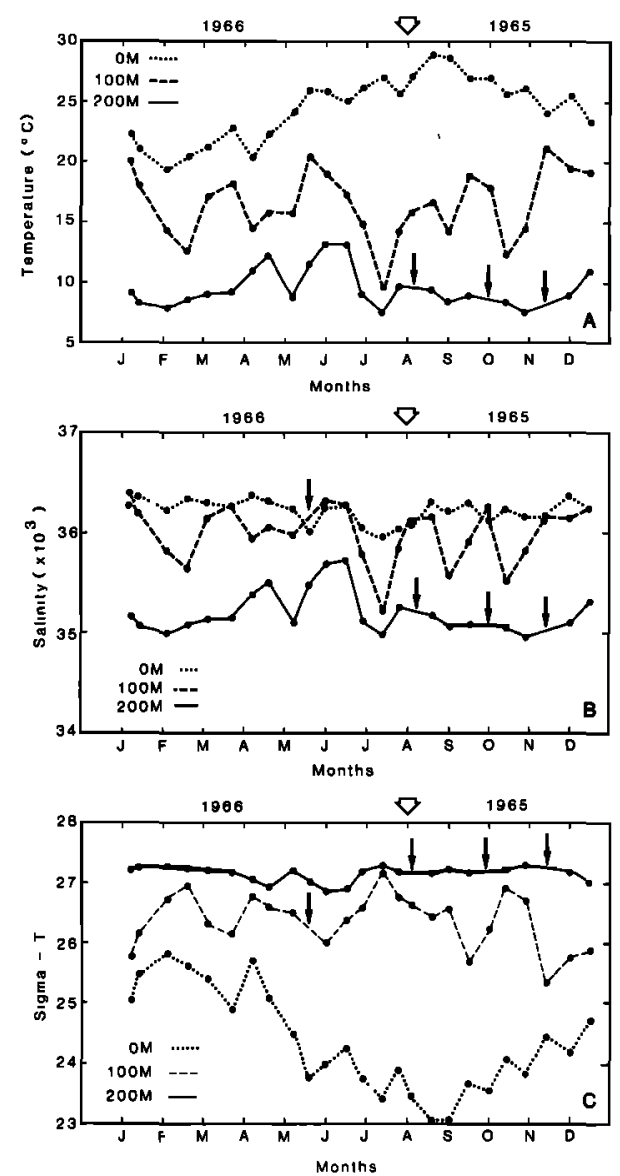

Fig. 5. Time series of bi-weekly observations of: (a) temperature, $(b)$ corresponding salinity, and (c) corresponding sigma $t$ at three depths at Peirce cruise stations 3 or 4 (Figure 4, line A) in the doming region. (The small arrows indicate no data and the large unshaded arrow indicates the beginning of the time series in August 1965.)

explained as responses to seasonal warming and cooling and compare favorably in trend with Chase [1971] for Frying Pan Shoals Light Station off Cape Fear. In addition, Chase [1969] has shown that historically the lowest mean surface salinities off Cape Fear occur in July.

Atkinson and Targett [1983] reported surface shelf break ( $60 \mathrm{~m}$ isobath) salinities lower than $36.00 \times 10^{-3}$ in late June 1980 between $31^{\circ}$ and $32^{\circ} 40^{\prime} \mathrm{N}$, suggesting an offshore flow of water in the region. Southwesterly winds, which occurred, favor such observations, causing low salinity shelf water to move offshore into the frictional drag of the Gulf Stream as suggested by Bumpus [1955]. Here, however, the shelf water first moves off-shelf into the doming region and then into the frictional drag of the Gulf Stream.

Interestingly, Weber and Blanton [1980] have found that southerly to southwesterly winds occur primarily in July in this area. This suggests for the annual cycle that the largest quantities of low salinity shelf water are moved off shelf en masse in the 'Bump' region in July. If this is in fact the case, then aerial mapping of surface salinity might define the path of the Gulf Stream in this area in July when surface temperature observations are inappropriate.

\section{$100 \mathrm{~m}$ Observations}

At $100 \mathrm{~m}$, higher temperatures corresponded to higher salinities and lower densities. Lower temperatures corre- 
sponded to lower salinities and higher densities. Observations at this depth oscillated between coupling with surface and deeper $(200 \mathrm{~m})$ observations. They were coupled to the surface in January and to the bottom in July. A periodicity of 2-3 months was observed.

\section{0 m Observations}

At $200 \mathrm{~m}$, the temperature, salinity, and density relationships were as noted above for the $100 \mathrm{~m}$ depth. Generally, the lowest temperatures were observed from January through March and July through November and the highest from April through June and December. Related trends are apparent in the $200 \mathrm{~m}$ salinity and sigma $t$ plots (Figures $5 b$ and $5 c$ ). When the $200 \mathrm{~m}$ data from the Gill and authors' cruises along sections B and C (Figure 4) are included with the Peirce data, the lowest temperature periods are narrowed to January-February and July-October, and the highest temperature periods are lengthened to March-June and November-December (Figure 6). These results compare favorably with Iselin's [1940] observations of the seasonal variation in the depth of the main thermocline layer $\left(12^{\circ}-\right.$ $6^{\circ} \mathrm{C}$ ) of the Gulf Stream's northern and southern edges between Montauk Point and Bermuda. There he noted that the isotherms of the main thermocline layer tended to be nearer the surface (cooler at $200 \mathrm{~m}$ ) in January and in the June-August period. Also, he noted a deepening of isotherms (warmer at $200 \mathrm{~m}$ ) in March or April and again in October or November. Subsequently, it appears that the 200 m observations off Cape Romain are coupled to seasonal variations in the main thermocline.

\section{Temperature-Salinity Correlations}

Figure 7 presents temperature-salinity (TS) correlations for seven of the nine cruises by the authors. The plots are from the same location off Cape Romain $\left(32^{\circ} 20.0^{\prime} \mathrm{N}\right.$ $78^{\circ} 25.0^{\prime} \mathrm{W}$ ) in the doming region in $305 \mathrm{~m}$ of water (station 'TS,' Figure 4, section C). These plots show seasonal warming of surface water between March and August and cooling between August and November. They also reveal that only in July did surface salinities fall significantly below $36 \times 10^{-3}$ (to as low as $35.62 \times 10^{-3}$ ) which further supports our earlier observations. In August, mid-depth water $\left(20^{\circ}-\right.$ $25^{\circ} \mathrm{C}$ ) exhibited the highest salinities. These were due to the high salinity core of the Gulf Stream, which had moved shoreward (see Figure 8f). In October, low salinities were observed in the $13^{\circ}-19^{\circ} \mathrm{C}$ range when a sharp thermocline $\left(5.6^{\circ} \mathrm{C}\right.$ over $5 \mathrm{~m}$ depth) may have caused CTD sensor

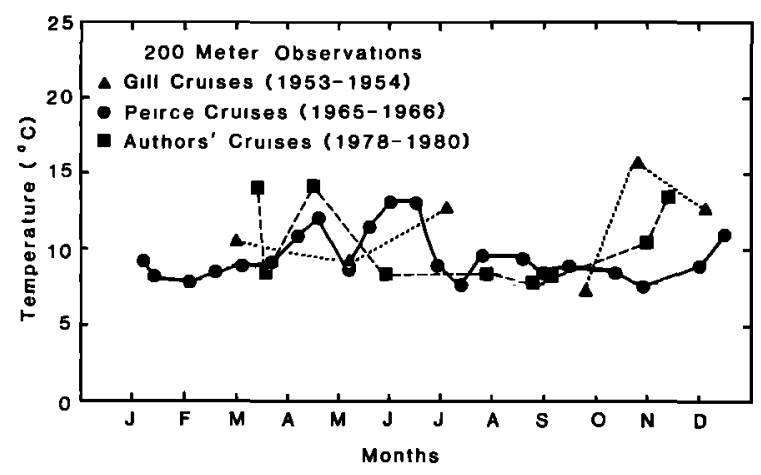

Fig. 6. Time series of observations of the lowest temperature at $200 \mathrm{~m}$ off Cape Romain for three different sampling periods.

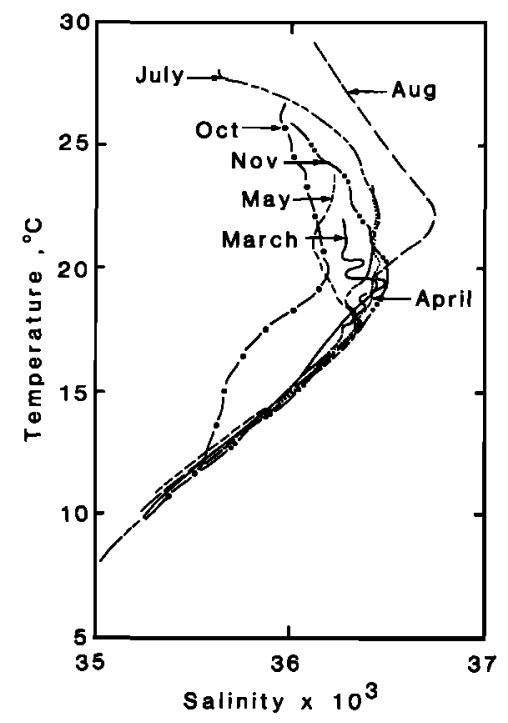
Fig. 7. Seven (7) TS plots off Cape Romain at $32^{\circ} 20.0^{\prime} \mathrm{N}$
$78^{\circ} 25.0^{\prime} \mathrm{W}$.

mismatch. However, in May (not shown), a station $35 \mathrm{~km}$ further offshore exhibited similar structure with a more gradual thermocline $\left(5.6^{\circ} \mathrm{C}\right.$ over $65 \mathrm{~m}$ depth), and Hazelworth [1976] has shown the occasional occurrence of similar structure at station 3 of the Peirce cruise data.

Repeated Vertical Sections of Salinity, Temperature, Nitrate, and Total Chlorophyll OfF CAPE RoMaIN

Vertical plots of salinity, temperature, nitrate, and total chlorophyll are presented in Figures 8-11. These correspond to the authors' cruises off Cape Romain (Table 2; Figure 4, section $\mathrm{C}$ ). Note that the only repeated cruise month was March.

\section{Salinity and Temperature}

Figures $8 b, 8 e, 8 f, 8 h, 9 b, 9 e, 9 f, 9 h$ show that the greatest upward penetration of cold, low salinity (and high density) water occurred in March 1979, July 1978, and August and October 1979; and the least in March, April, and November 1978 (Figures $8 a, 8 c, 8 i, 9 a, 9 c, 9 i$ ). These same observations (for temperature) were presented graphically in Figure 6 and have been discussed as relating to an apparent variation in the seasonal thermocline. If that is the case, then the fact that March exhibits both a maximum and minimum may indicate that it is a transitional month. May 1979 and September 1980 (Figures $8 d, 8 g, 9 d, 9 g$ ) appear as intermediates.

The temperature structure of Figure 9 shows that doming (as defined earlier) may or may not be observed along this section. This is not surprising in view of the frequency of occurrence statistics reported earlier. There is also a sharp structural contrast between March 1978 and March 1979 (Figures $9 a$ and $9 b$ ). The 1978 observations were coincident with SW-SSW winds (5-25 kn) and the 1979 observations corresponded to a period of ENE-E winds (5-15 kn). Since the Gulf Stream was approximately the same distance offshore for both periods ( $<10 \mathrm{~km}$ difference), it is possible that the winds were in part responsible for the structural differences (i.e., changing wind patterns probably affect the intensity of flow on the western side of the dome). Northerly 


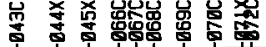

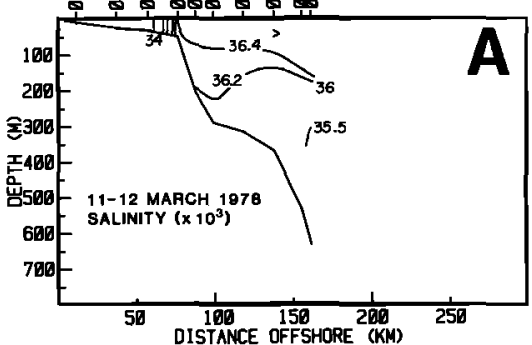

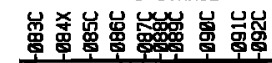

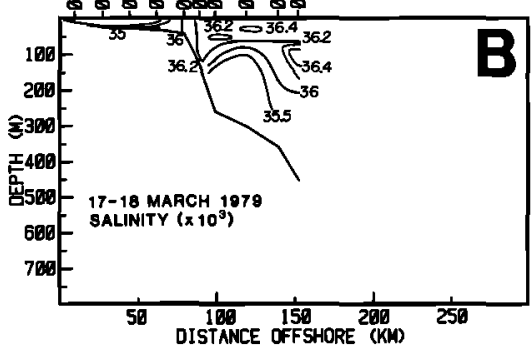

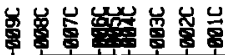

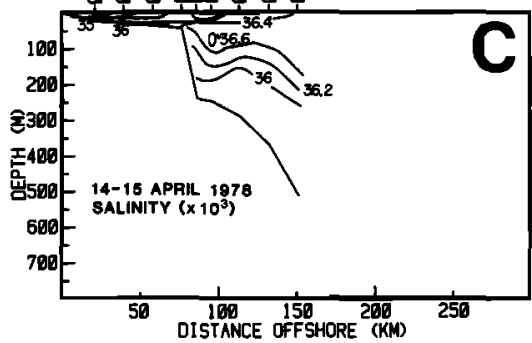

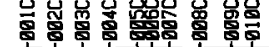

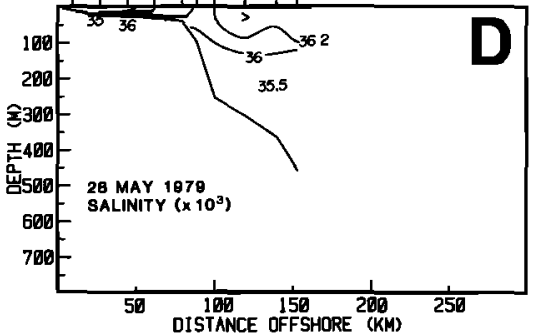

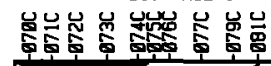

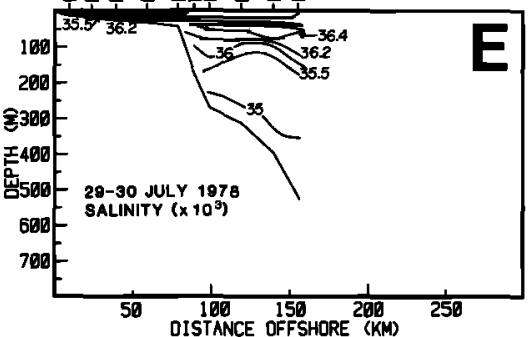

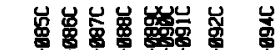

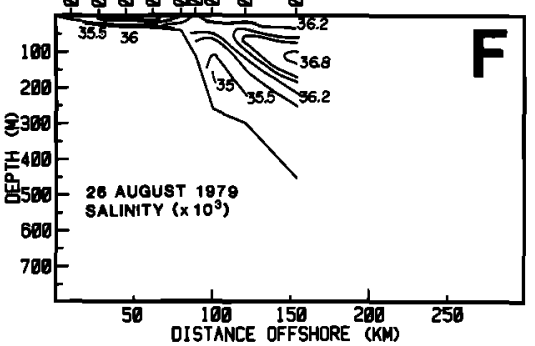

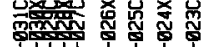

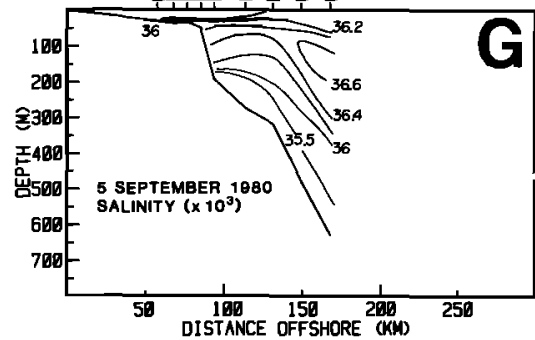

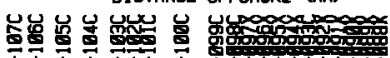

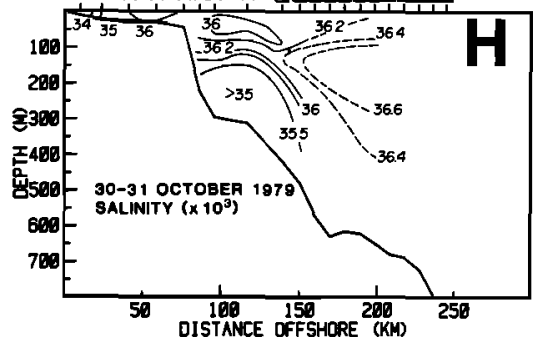

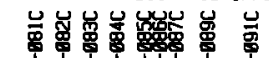

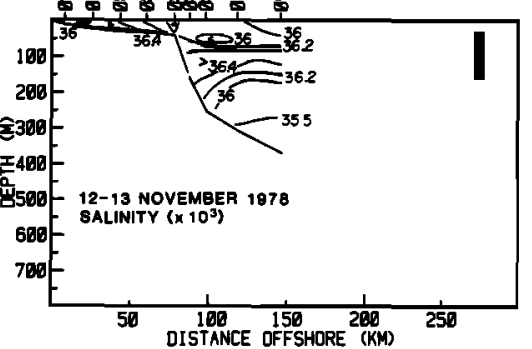

Fig. 8. Vertical salinity data for nine cruises by the authors (Cape Romain section): $C=C T D$ station: $X=X B T$ station.
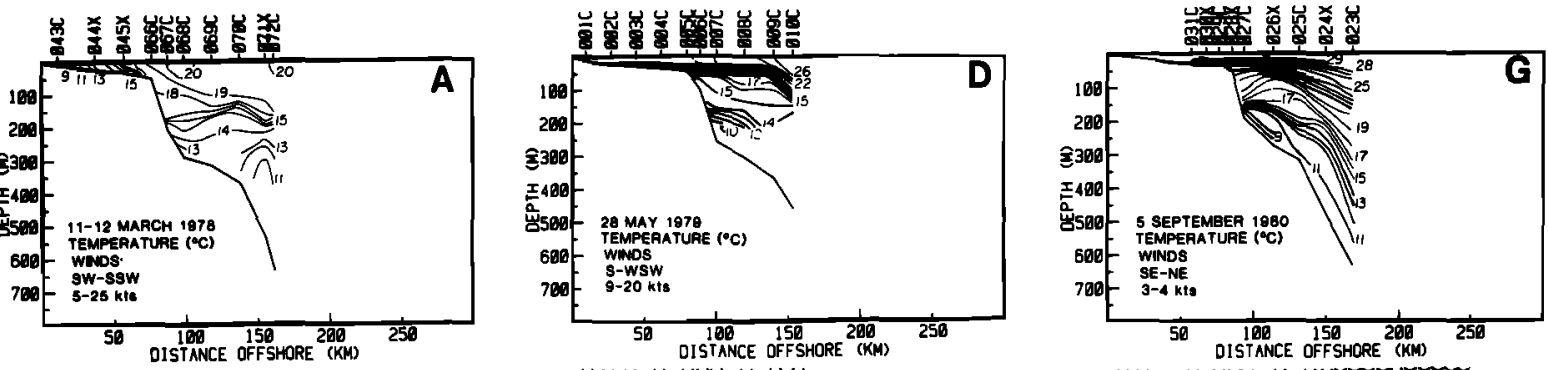

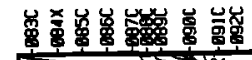
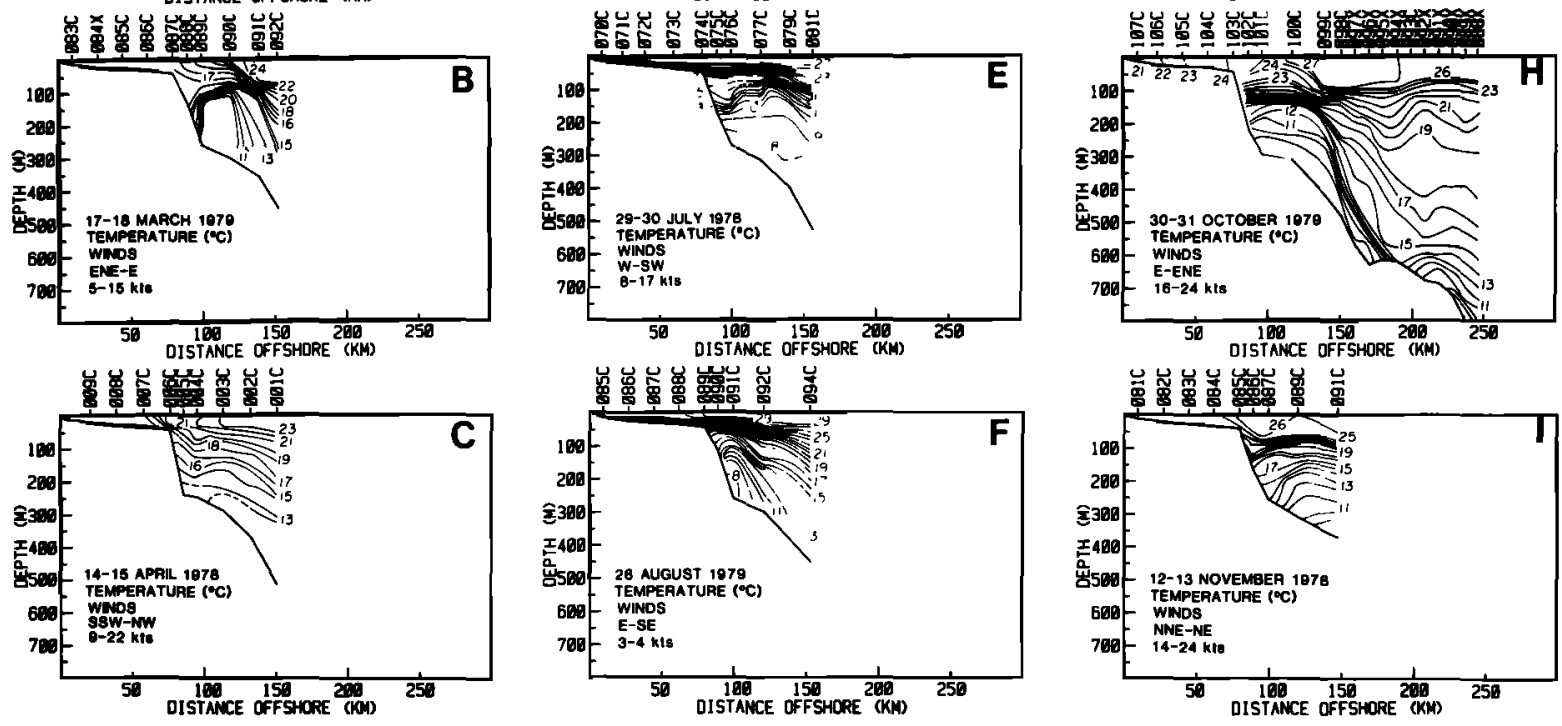

Fig. 9. Vertical temperature data for nine cruises by the authors (Cape Romain section). 

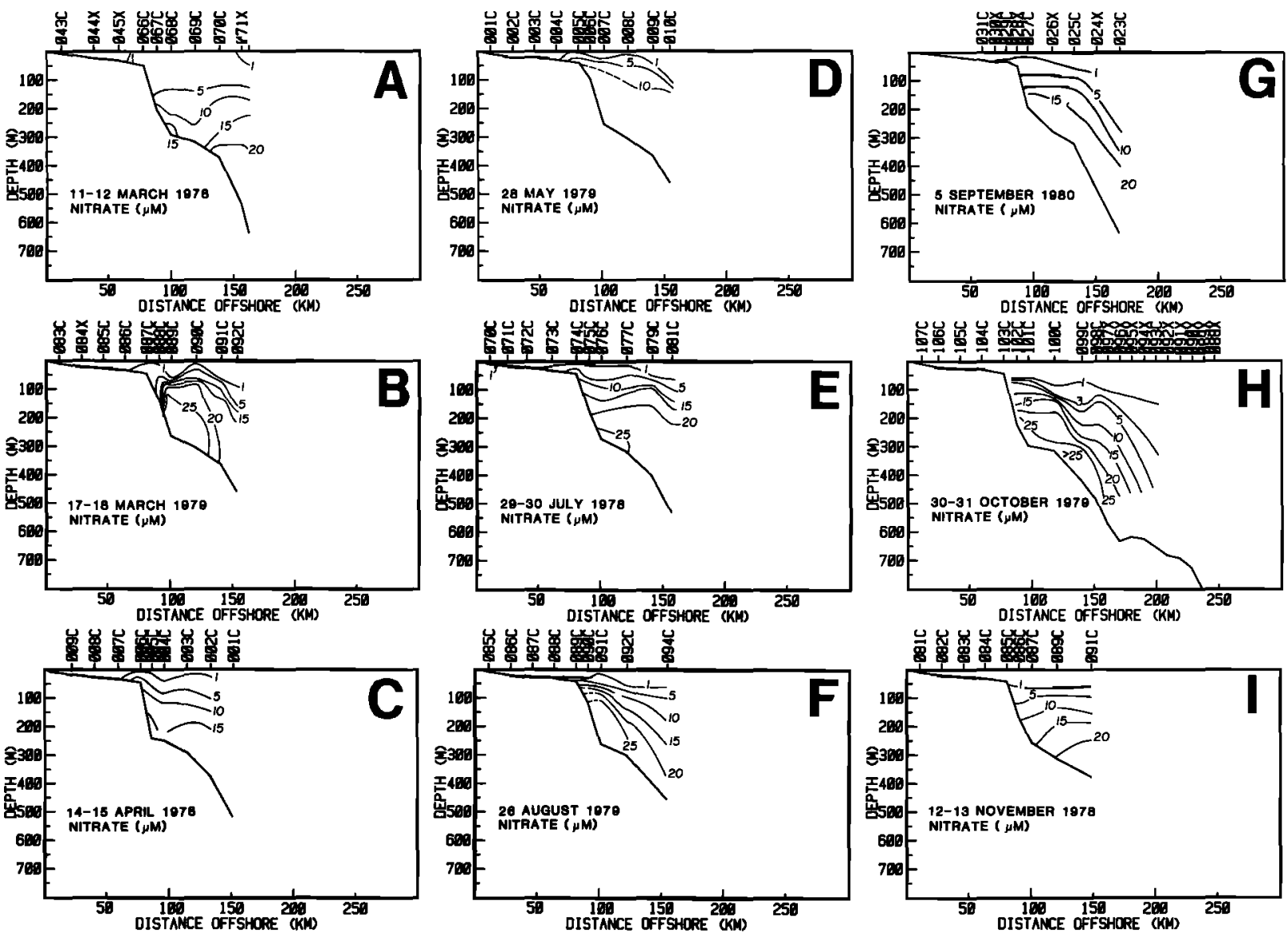

Fig. 10. Vertical nitrate data for nine cruises by the authors (Cape Romain section).

winds could increase cyclonic flow and tighten the dome, whereas southwesterly winds should decrease cyclonic flow and broaden the dome. This relationship appears generally to apply for all periods with wind speeds greater than $5 \mathrm{kn}$.

\section{Nitrate}

The greatest upward nitrate penetration occurred for the same months (March 1979, July 1978, and August and October 1979; Figures $10 b, 10 e, 10 f, 10 h$ ) as exhibited the greatest upwelling of cold, low salinity (and high density) waters. However, high near-surface nitrate levels (1-5 $\mu \mathrm{M}$ ) were also observed in March and April 1978 and May 1979 (Figures $10 a, 10 c, 10 d$ ) when surface waters were less than $22-23^{\circ} \mathrm{C}$. This is probably explained by the nitrate-temperature relationship of Atkinson et al. [1978] which suggests that high surface nitrate levels can be sustained longer at such temperatures than at the higher surface temperatures of July 1978 and August 1979. Subsequently, the high springtime surface levels are probably of older upwelled origin than those observed in July and August.

\section{Chlorophyll}

Chlorophyll data were collected in the upper $200 \mathrm{~m}$ along this section. The highest total chlorophyll concentrations (chlorophyll- $a$ plus phaeopigment- $a$ ) occurred during two of the four periods of strong upwelling: March 1979 and July 1978 (Figures $11 b, 11 e$ ). These observations were associated with the leading edge of strong thermal gradients at tempera- tures less than $17^{\circ} \mathrm{C}$ (Figures $9 b, 9 e$ ) with nitrate concentrations greater than $10 \mu \mathrm{M}$ (Figures $10 b, 10 e$ ).

In the absence of upwelling offshore of the shelf break and in the Gulf Stream, one would expect total chlorophyll values less than $0.1-0.2 \mathrm{mg} / \mathrm{m}^{3}$ at the surface [Bishop et al., 1980]. Here, however, offshore of the break, five of the nine sections exhibited higher values at the surface and seven exhibited higher values in the upper $50 \mathrm{~m}$. The highest value observed was $3.1 \mathrm{mg} / \mathrm{m}^{3}$ at $70 \mathrm{~m}$ in July 1978 (Figure 11e). In contrast, surface values as high as $5.0 \mathrm{mg} / \mathrm{m}^{3}$ have been observed further south in the SAB during upwelling events associated with meanders and frontal eddies [Bishop et al., 1980; Yoder et al., 1981]

\section{Gulf Stream Deflection Off Long Bay}

Temperature data from the Gill and Dolphin cruises and two of the authors' cruises (March 1978 and October 1979) were examined in the horizontal at $150 \mathrm{~m}$ depth (Figure 12). These cruises were selected because they provide sufficient data collected off Cape Romain, Long Bay, and Cape Fear to permit contouring of the region. The only other comprehensive data in the literature identified for this region are the AXBT data for November and February 1979 reported by Bane et al. [1980a] and Bane and Brooks [1981] of which Bane et al. [1981] and Bane [1983] are subsets.

A depth of $150 \mathrm{~m}$ was selected for presentation as fewer data are available at the $200 \mathrm{~m}$ level. Shallower depths $(0,50$, and $100 \mathrm{~m}$ ) were ignored since they are more susceptible to 

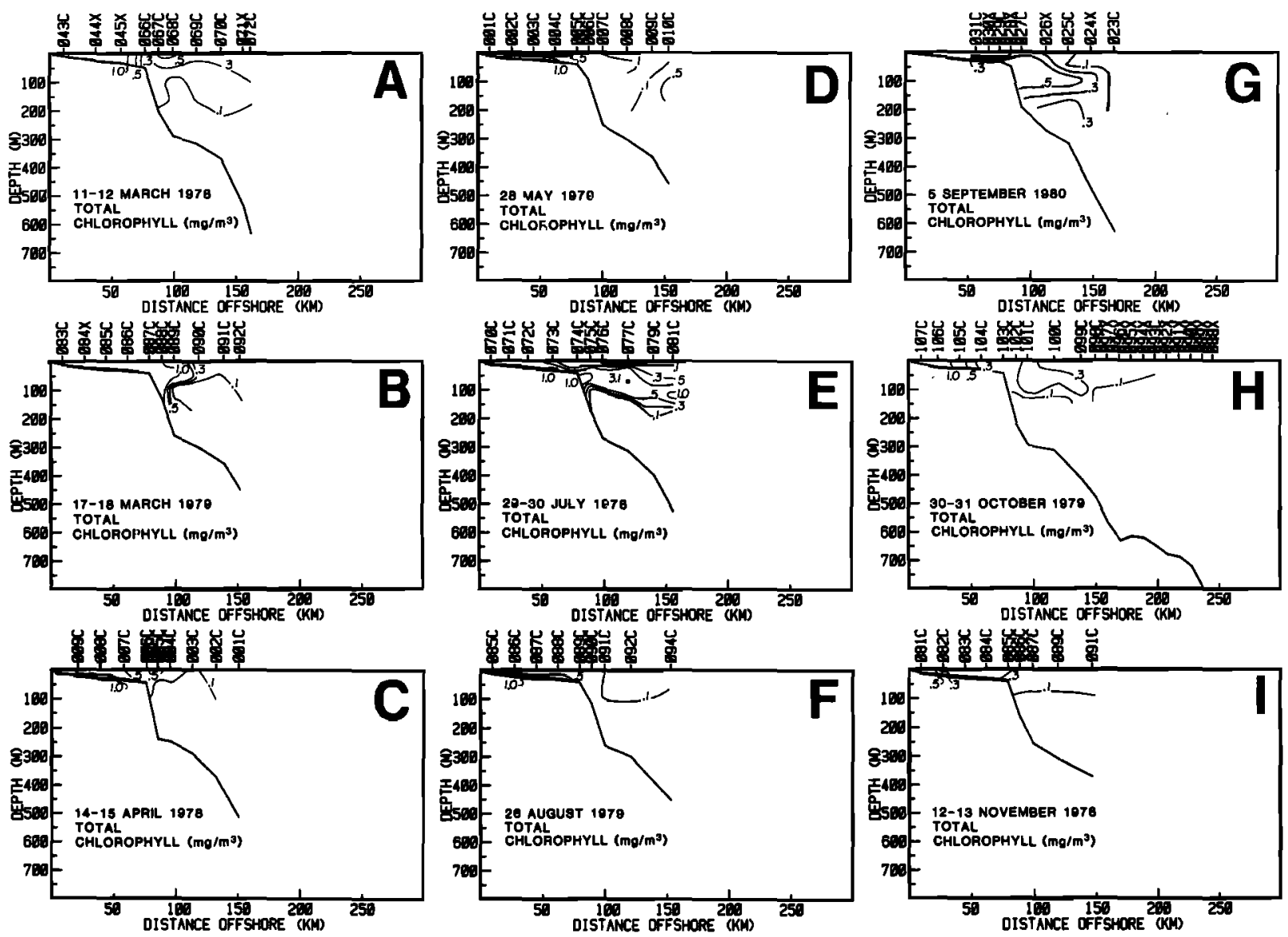

Fig. 11. Vertical total chlorophyll data for nine cruises by the authors (Cape Romain section).

seasonal warming and cooling. The $17^{\circ}-17.5^{\circ} \mathrm{C}$ isotherm is indicative of the Gulf Stream's western boundary at the 150 $\mathrm{m}$ level. The horizontal spacing of the isotherms in Figure 12 should be representative of the trends, but they are not presumed to be absolutely accurate as to the width of the gradient along the western edge of the Stream. Obviously, the 'total area' short-term synopticity is in question for Figures $12 c, 12 f$, and $12 k$ where sampling occurred over 12 30 days. However, most of the data were collected over a period of 3-6 days.

\section{Processes}

Before examining these data, it is pointed out that there seem to be two different processes occurring in the region. First, as noted earlier from the Hazelworth [1976] data, there appears to always be an offshore deflection of the Gulf Stream from the $200 \mathrm{~m}$ isobath. Second, periodic meanders appear to amplify this deflection, at least in surface infrared imagery. The work of Bane et al. [1981] suggests that the influence of these meanders may be felt to depths in excess of the $150 \mathrm{~m}$ used here. However, they also point out that the offshore deflection has been observed to decrease with depth. Subsequently, the observations presented in Figure 12 may or may not include the influence of meander events, as they cannot be ascertained from the existing data.

\section{General Observations}

The data indicate that throughout the year the Gulf Stream moves offshore, and an upwelling region is formed in the offing of Long Bay. Second, at times there is a gradual offshore-onshore movement roughly following the $400 \mathrm{~m}$ isobath (Figures $12 h, 12 i, 12 j$ ) and at other times an abrupt eastward movement near $32^{\circ} \mathrm{N}$ (Figures $12 a, 12 c, 12 e, 12 g$ ). This latter observation is highly correlated to a greater offshore movement of the Gulf Stream opposite Long Bay. Third, seasonally, the least movement offshore opposite Long Bay occurred in the August through November period, and the greatest movement offshore occurred in the February through March, May, and July periods. The July deflection was particularly large. Interestingly, these same time frames are nearly identically reproduced by the authors' repeated section off Cape Romain (Figure 9) for much shorter sampling intervals ( $<12$ hours). There, seasonally, the least deflection from the $\mathbf{2 0 0} \mathrm{m}$ isobath occurred in April and August through October (Figures $9 c, 9 f, 9 g, 9 h$ ) and the greatest deflection occurred in March 1978, May, July, and November (Figures 9a, 9d, 9e, 9i). Only the November observation is contradictory with the above. Figure $12 a$ shows the authors' section (line $C$ ) with respect to the horizontal field. Clearly, this section would have been a good indicator of the relative offshore deflection opposite Long Bay for 9 of the 12 composites presented in Figure 12.

\section{Deflection Range Along Line A}

Line $A$ is shown in Figure 12a. It is the cruise track for the Peirce cruises. The deflection offshore from station 3 (Figure 4 , line A) along this section has been determined relative to the mean for all the data. This information is presented in Figure 13. The Gulf Stream was defined as the $15^{\circ} \mathrm{C}$ isotherm 

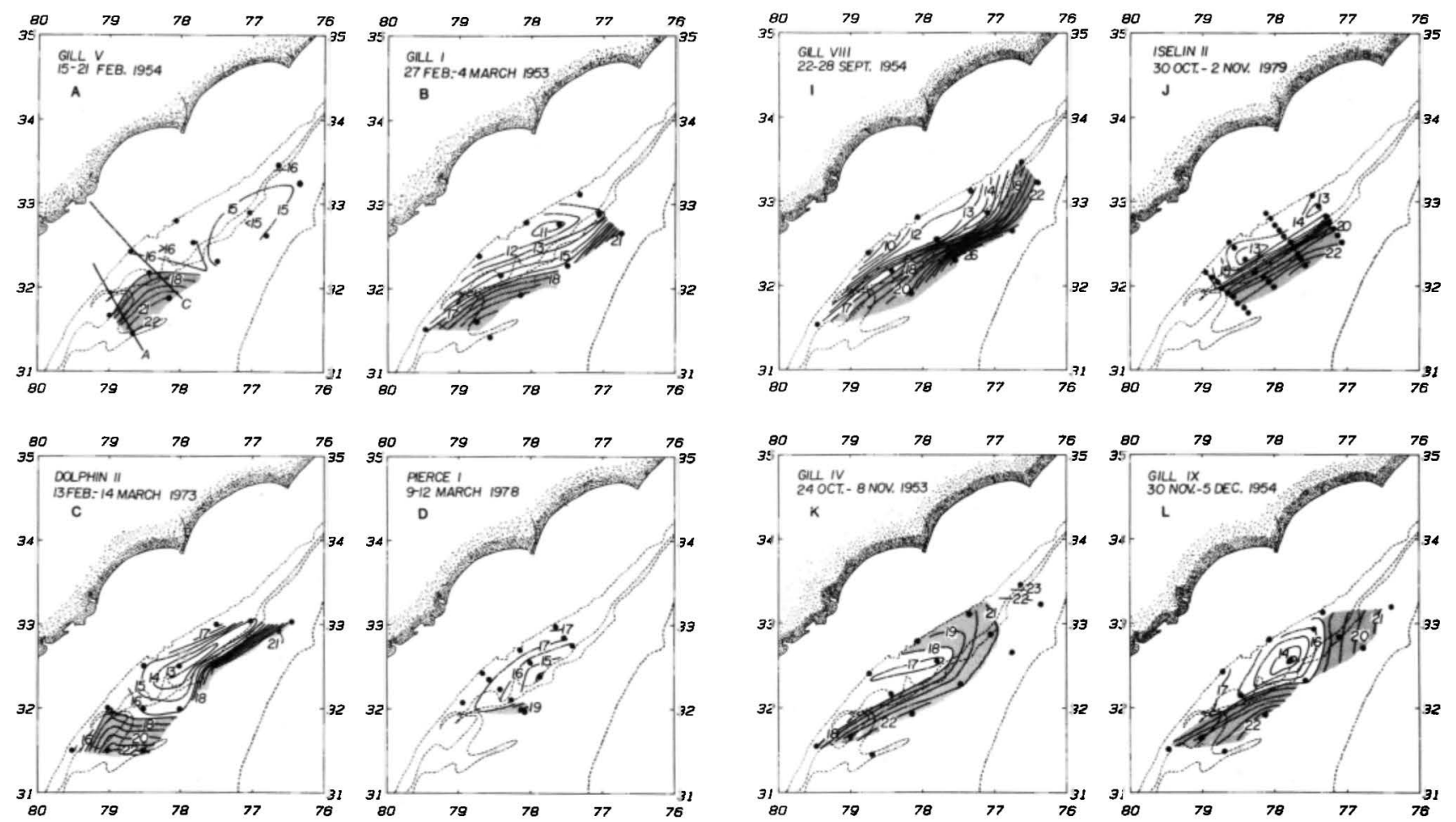

Fig. 12. (continued)

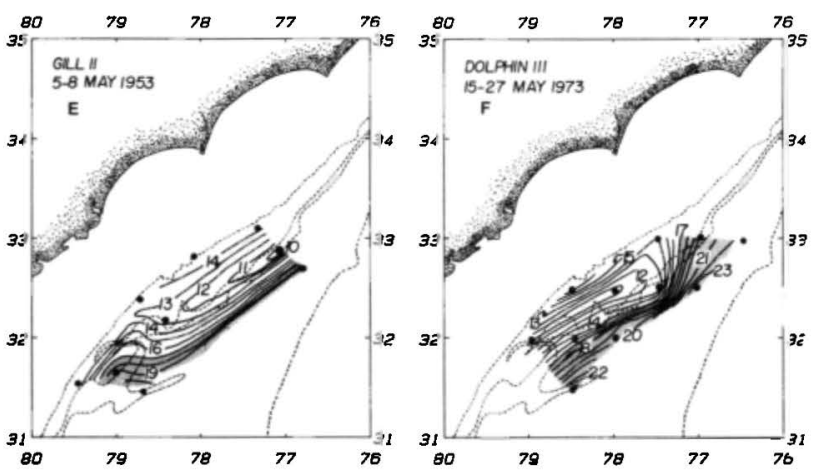

at $200 \mathrm{~m}$, and the distances were obtained from the vertical plots of temperature presented by Hazelworth [1976]. Examination of station locations reveals that the same section at the furthest applicable offshore extent but had comparable across-shelf station spacing $(18.5 \mathrm{~km})$.

The range of deflection was nearly $38 \mathrm{~km}$, with maximum and minimum distances from station 3 of 56.4 and $18.5 \mathrm{~km}$, respectively. The mean distance was $35.6 \mathrm{~km}$. The shortterm variability over 2-week periods was as much as $32 \mathrm{~km}$ (in August) but generally less than $21 \mathrm{~km}$. Seasonally, the least offshore movement occurred in March, mid-August, and early December and the greatest in May, June, early August, and early November. These observations contradict our earlier findings for March but also suggest a transitional period for November, thereby possibly explaining the contradiction of the Cape Romain section cited above. In addition, by applying this section to the plots of Figure 12, the February-March period would exhibit both large and small deflections along this line, and the relative deflection opposite Long Bay would be predicted accurately 7 of 10 times.

\section{Gulf Stream Transport and Deflection}

Between April and August 1966, transport measurements were made corresponding to eight of the Peirce cruises. These values from Hazelworth [1976] are reported (in boxes) in Figure 13 and are the average of two values believed in error by no more than $\pm 10 \%$. The first five of these values suggest a direct relationship between Gulf Stream transport and the relative distance offshore from station 3 . However, the latter two observations, in particular, appear to contradict this trend.

Fuglister [1951] reported that the minimum and maximum currents for this region occur in November and July, respectively, and Montgomery [1938] has shown that sea level data

reproduced through stations 4,5 , or 6 as applicable furthest offshore extent of the western wall of the Gulf Stream) for 16 of the sections. Four other sections showed SW or NE alongshore displacement between 7.4 and $17.6 \mathrm{~km}$ 


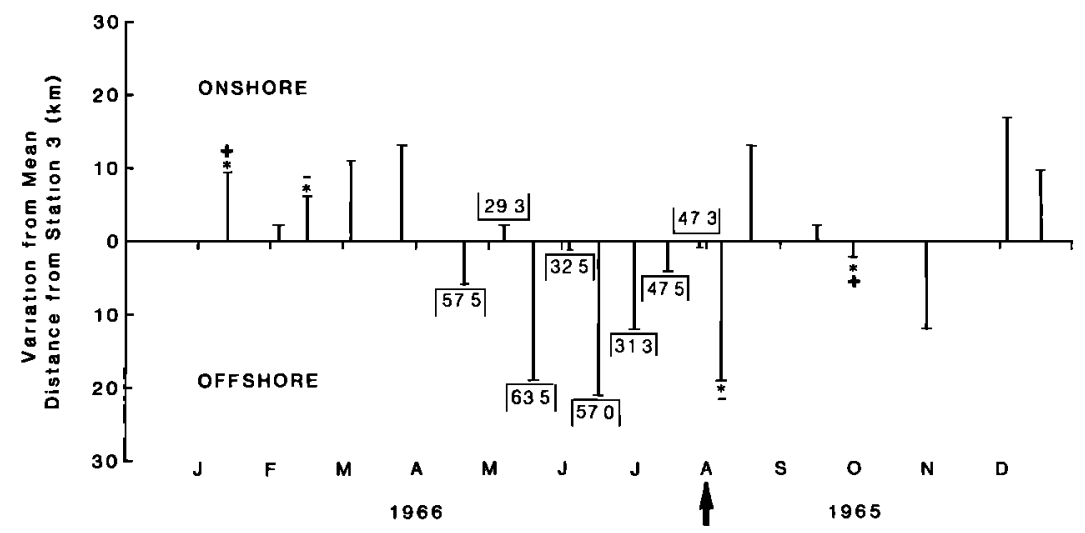

Fig. 13. Onshore-offshore variation in the distance of the Gulf Stream western wall from the mean from station 3 along line A (August 1965 to July 1966). Boxed numbers are estimated mean transport $\left(\times 10^{6} \mathrm{M}^{3} / \mathrm{s}\right)$ from Hazelworth [1976]: (Asterisk $=$ As measured between 7.4 and $17.6 \mathrm{~km}$ from the standard stations in \pm alongshore direction (minus, SW; plus, NE)).

indicate minimum and maximum flow generally occur in October and July, respectively. There is also some indication that a secondary minimum occurs in April and a secondary maximum in January. Niiler and Richardson [1973] have presented evidence of an annual cycle to Gulf Stream transport for the Florida Straits. Their data suggest a similar time frame with minimums and maximums occurring in December and June, respectively. Interestingly, Brooks [1979] and Düing [1975] have both indicated that an eastward displacement of the Gulf Stream axis in the Florida Straits usually corresponds to an increase in transport. Correlation of these findings with those above suggests that frequently there is a direct relationship between transport and deflection. In contrast, the latter three observations of the transport opposite station 3 of the Peirce cruise data tend to support the view of Rooney et al. [1978] that higher (lower) velocities would induce lesser (greater) deflection. Perhaps the differences between these and the other five observations are attributable to changes in the angle of incidence of the Gulf Stream into the region or there is some other unidentified factor of influence. However, if the late June observation could be identified as an explainable anomaly (which will not be attempted here), the latter two observations would remain consistent with the earlier arguments.

A direct relationship might in part be explained by adherence to Iselin's [1938] theory of the circulation of the North Atlantic. He proposed a large anti-cyclonic eddy that contracts as transport increases and presses closer to the coast as transport decreases. In the 'Bump' region, the increasing current speed would deepen the Gulf Stream and increase its sensitivity to the bathymetry further offshore. A decreasing current speed would decrease its depth and sensitivity to the offshore bathymetry, and the Stream would move nearer shore but still be well offshore of the $200 \mathrm{~m}$ isobath.

As a corollary, if cyclonic flow is in fact generated off Long Bay, one would expect it to decrease with the Stream offshore particularly with southwest winds blowing against a southward return on its western side (creating a larger, more diffuse cyclone) and to increase with the Stream onshore, particularly with northeast winds enhancing southward flow on its western side (creating a smaller, tigher cyclone). Such seasonal onshore-offshore motion associated with current strength could explain much of the implied seasonal temperature structure in the doming region presented earlier in
Figures 5 and 6. Hazelworth [1976] in fact directly credited the thermocline fluctuations in this area to 'meanderings of the Gulf Stream,' and Iselin [1938] has noted in the deep ocean that 'As the current decreases in strength, bottom temperatures in the depths occupied by the main thermocline layer will rise and vice versa.' This could readily explain the low temperatures observed in July but creates a problem for October if one accepts the seasonal transport trends suggested by Montgomery [1938] as cited above. The seasonal occurrence of northeast winds in October [Weber and Blanton, 1980], however, may compensate for the implied seasonal onshore movement of the Stream which would otherwise deepen the thermocline.

It is noted that in addition to seasonal (several month) variations in the strength of the Gulf Stream, Iselin [1940] has shown that there are year-to-year variations in the mean Gulf Stream transport, and Schmitz and Richardson [1968] have shown (for the Florida Straits) that $75 \%$ of the range over 3 years may be observed in 1 month. Brooks [1979] has narrowed the occurrence of that range to 4-14 days, and the transport values presented in Figure 13 would tend to support those findings as being applicable to the 'Bump' region as well. The existence of such short-term variations may also explain the observed deviations from the implied seasonal deflection trends presented above.

\section{Summary AND Conclusions}

Doming was defined for a cross-shelf section as an upward and then downward bending of the $15^{\circ} \mathrm{C}$ isotherm offshore of the $200 \mathrm{~m}$ isobath. A region where such doming was observed was noted as extending between $31.5^{\circ}$ and $34.5^{\circ} \mathrm{N}$. This is the same region over which the $400 \mathrm{~m}$ isobath extends offshore and then back onshore with regard to the $200 \mathrm{~m}$ bathymetry. Nearly $75 \%$ of all doming observations occurred in the area between the 200 and $400 \mathrm{~m}$ isobaths. The incidence of doming for seasonal repeated sections in the SAB (from the Gill cruises) was found to be $86 \%$ off Long Bay, 38\% off Cape Fear, and $25 \%$ off Cape Romain. The higher incidence off Long Bay tends to support the view of Pietrafesa and Janowitz [1980] and Pietrafesa [1983] that a cyclonic circulation pattern persists throughout much of the year in the region.

Evidence was presented showing that lower salinity shelf water moves offshelf and is observable in the doming region 
off Long Bay between late June and early August. This was attributed to the occurrence of sustained southerly to southwesterly winds and is probably a seasonal occurrence. Aerial mapping of surface salinity was suggested as a means of quickly defining the path of the Gulf Stream in the area in July when surface temperature gradients are too small to satisfactorily define the western wall of the Gulf Stream.

Temperatures at $200 \mathrm{~m}$ depth suggest seasonal fluctuations in the depth of the main thermocline layer $\left(12^{\circ}-6^{\circ} \mathrm{C}\right)$ and subsequent source nutrient levels in the doming region. The colder waters tended to be more shallow for JanuaryFebruary and July-October and deeper for March-June and November-December.

Along the Cape Romain section, the greatest upward nitrate penetration occurred for the same months that exhibited the greatest upwelling of cold, low salinity (and high density) water (i.e., March 1979, and in summer and early fall). However, near-surface nitrate levels of 1-5 $\mu \mathrm{M}$ were observed in March and April 1978 and May 1979 when weaker upwelling was observed. These high springtime surface values were probably of older upwelled origin, being sustained by the cooler $\left(<22^{\circ}-23^{\circ} \mathrm{C}\right)$ surface temperatures.

The highest total chlorophyll observations $\left(\leqq 3.1 \mathrm{mg} / \mathrm{m}^{3}\right)$ were made in March 1979 and July 1978. These observations were associated with the leading edge of strong thermal gradients at temperatures less than $17^{\circ} \mathrm{C}$ with nitrate concentrations greater than $10 \mu \mathrm{M}$. Such values are not as high as have been observed further south in the SAB during upwelling events associated with meanders and frontal eddies (5.0 $\mu \mathrm{M})$. However, since no special effort was made to sample the region in as much detail (tighter station density and more sampling depths), these total chlorophyll observations should be regarded as background for future work.

Throughout the year the Gulf Stream moves offshore of the $200 \mathrm{~m}$ isobath and an upwelling region is formed in the offing of Long Bay. At times there is a gradual offshoreonshore movement roughly following the $400 \mathrm{~m}$ isobath and at other times and abrupt eastward movement near $32^{\circ} \mathrm{N}$. Much of the time there appears to be an agreement between the historical seasonal transport and offshore deflection, with greater deflection occurring during the season of higher transport (summer) and vice versa. Iselin's [1938] theory of North Atlantic circulation may in part explain these observations. The large anti-cyclonic eddy of the North Atlantic contracts and deepens (moving the Gulf Stream offshore) as transport increases and expands and shoals (moving the Gulf Stream onshore) as transport decreases.

This same theory predicts a larger, more diffuse cyclonic circulation off Long Bay for high Gulf Stream transport and a smaller, tighter cyclonic circulation for lower Gulf Stream transport. In effect, a small eddy is driven by a larger one. It has also been noted that the local winds might enhance or retard such cyclonic flow and that the depth of the main thermocline layer in the doming region is suggestive of a direct seasonal response to the relative transport of the Gulf Stream and the local wind.

Acknowledgments. The authors wish to thank ti. saplains and crews of the R/V Columbus Iselin, the R/V Eastward, and the $G . W$. Pierce (Tracor Marine) for their help in the collection of hydrographic data. Special thanks go to Steve Lasley, Paul Galbreath, Bob Guest, and numerous other technicians and students from the University of Miami and Skidaway Institute of Oceanography who participated in these cruises. Lucretia Garrigan (Duke University
Marine Lab), Pat O'Malley, and Steve Lasley are all thanked for nutrient analysis. Very special thanks are extended to Bill Chandler, who not only participated in all of the authors' cruises as chief programer and as an oceanographic technician, but who also interpreted and accessed the data tapes acquired from NODC. Joe Karpen (SAI) is thanked for some of the initial data products. Barbara Ries, Lynn O'Malley, and Suzanne McIntosh are thanked for their graphics work, and Linda Land and Cindy Miller are thanked for typing the text. The comments and suggestions of John Bane, Jr., Tom Lee, and Len Pietrafesa are gratefully acknowledged as they were kind enough to review an early version of this manuscript. In addition, the additional historical background provided by one of the reviewers is acknowledged. This work was supported by BLM under contract 520-02 to Science Applications, Inc., and DOE under contract DE-AS09-76-EV00889 to Larry Atkinson.

\section{REFERENCES}

American Association of Petroleum Geologists, Bathymetric Maps, Eastern Continental Margin, U.S.A., Atlantic Ocean South of Cape Hatteras, sheet 2 of 3, 1970.

Anderson, W., J. Gehringer, and E. Cohen, Physical oceanographic, biological and chemical data: South Atlantic Coast of the United States, Spec. Sci. Rep. Fish. 178, U.S. Fish and Wildlife Serv., Washington, D.C., $1956 a$.

Anderson, W., J. Gehringer, and E. Cohen, Physical oceanographic, biological, and chemical data: South Atlantic Coast of the United States, Gill Cruise 2, Spec. Sci. Rep. Fish. 198, U.S. Fish and Wildlife Serv., Washington, D.C., $1956 b$.

Anderson, W., and J. Gehringer, Physical oceanographic biological and chemical data: South Atlantic Coast of the United States, Gill Cruise 3, Spec. Sci. Rep. Fish. 210, U.S. Fish and Wildlife Serv., Washington, D.C., $1957 a$.

Anderson, W., and J. Gehringer, Physical oceanographic, biological and chemical data: South Atlantic Coast of the United States, Gill Cruise 4, Spec. Sci. Rep. Fish. 234, U.S. Fish and Wildlife Service, Washington, D.C., $1957 b$.

Anderson, W., and J. Gehringer, Physical oceanographic, biological, and chemical data: South Atlantic Coast of the United States, Gill Cruise 5, Spec. Sci. Rep. Fish. 248, U.S. Fish and Wildlife Serv., Washington, D.C., 1958.

Anderson, W., and J. Gehringer, Physical oceanographic, biological and chemical data: South Atlantic Coast of the United States, Gill Cruise 7, Spec. Sci. Rep. Fish. 278, U.S. Fish and Wildlife Serv., Washington, D.C., $1959 a$.

Anderson, W., and J. Gehringer, Physical oceanographic, biological and chemical data: South Atlantic Coast of the United States, Gill Cruise 8, Spec. Sci. Rep. Fish. 303, U.S. Fish and Wildlife Serv., Washington, D.C., 19596 .

Anderson, W., and J. Gehringer, Physical oceanographic, biological and chemical data: South Atlantic Coast of the United States, Gill Cruise 9, Spec. Sci. Rep. Fish. 313, U.S. Fish and Wildlife Serv., Washington, D.C., $1959 c$.

Atkinson, L. P., The results of four oceanographic cruises in the Georgia Bight, Tech. Rep. 78-1, Georgia Mar. Sci. Center, Savannah, 1978.

Atkinson, L. P., G.-A. Paffenhöfer, and W. M. Dunstan, The chemical and biological effect of a Gulf Stream intrusion off St. Augustine, Florida, Bull. Mar. Sci., 28(4), 667-679, 1978.

Atkinson, L. P., A. L. Edwards, J. J. Singer, W. S. Chandler, and G.-A. Paffenhöfer, Hydrographic observations in the Georgia Bight (July 1977), Tech. Rep. 79-3, Georgia Mar. Sci. Center, Savannah, 1979.

Atkinson, L. P., and T. E. Targett, Upwelling along the $60-\mathrm{m}$ isobath from Cape Canaveral to Cape Hatteras and its relationship to fish distribution, Deep Sea Res., 30, in press, 1983.

Bane, J. M., Jr. Initial observations of the subsurface structure and short-term variability of the seaward deflection of the Gulf Stream off Charleston, South Carolina, J. Geophys. Res., 88, this issue.

Bane, J. M., Jr., and D. A. Brooks, Gulf Stream Meanders along the continental margin from the Florida Straits to Cape Hatteras, Geophys. Res. Lett., 6(4), 280-282, 1979.

Bane, J. M., Jr., D. A. Brooks, and M. J. Ignaszewski, The Gulf Stream Meanders Experiment: Hydrographic data report, R/V Endeavor cruises EN-040 and EN-045, Rep. 80-10-T, Texas A\&M Univ., College Station, 1980. 
Bane, J. M., Jr., D. A. Brooks, K. R. Lorenson, and C. M. Seay, The Gulf Stream Meanders Experiment: AXBT/PRT data report, R/A Project Birdseye flights February 9-18, 1979, Tech. Rep. CMS-80-2, Univ. of North Carolina, Chapel Hill, 1980a.

Bane, J. M., Jr., D. A. Brooks, K. R. Lorenson, and C. M. Seay, Three-dimensional view of a Gulf Stream meander between Savannah, Ga. and Cape Hatteras, N. C., Gulf Stream, 5, 3-7, $1980 b$.

Bane, J. M., Jr., and D. A. Brooks, The Gulf Stream Meanders Experiment: AXBT/PRT data report, R/A Project Seascan flights November 21-29, 1979, Tech. Rep. CMS-81-I, Univ. North Carolina, Chapel Hill, 1981.

Bane, J. M., Jr., D. A. Brooks, and K. R. Lorenson, Synoptic observations of the three-dimensional structure and propagation of Gulf Stream Meanders along the Carolina continental margin, J. Geophys. Res., 86(C7), 6411-6425, 1981.

Bartlett, J. R., Deep-sea soundings and temperatures in the Gulf Stream off the Atlantic coast, Proc. Am. Assoc. Advance. Sci., $31,349-352,1883$.

Bishop, S. S., J. A. Yoder, and G.-A. Paffenhöfer, Phytoplankton and nutrient variability along a cross-shelf transect off Savannah, Georgia, U.S.A., Estuar. Coastal Mar. Sci., 11, 359-368, 1980.

Brooks, D. A., and J. M. Bane, Jr., Gulf Stream deflection by a bottom feature off Charleston, South Carolina, Science, 20I, 1225-1226, 1978

Brooks, D. A., J. M. Bane, Jr., and M. J. Ignaszewski, The Gulf Stream Meanders Experiment: Hydrographic data report, $R / V$ Endeavor cruises EN-031 and EN-037, Rep. 80-1-T, Texas A\&M University, College Station, 1980.

Brooks, I. H., Fluctuations in the transport of the Florida current at periods between tidal and two weeks, J. Phys. Oceanogr., 9. 1048-1053, 1979.

Bumpus, D. F., The circulation over the continental shelf south of Cape Hatteras, Trans. AGU, 36(4), 601-611, 1955.

Busby, R. F., The drift of the Ben Franklin, Gulf Stream, 3(8), 2-3, 1969.

Chandler, W. S., L. P. Atkinson, J. J. Singer, P. G. O'Malley, and C. V. Baker, A CTD System: Description, operation, data acquisition and processing, Tech. Rep. 78-7, Georgia Mar. Sci. Center, Savannah, 1978.

Chao, S., and G. S. Janowitz, The effect of a localized topographic irregularity on the flow of a boundary current along the continental margin, J. Phys. Oceanogr., 9, 900-910, 1979.

Chase, J., Surface salinity along the east coast of the United States, Deep Sea Res., 16 (Suppl.), 25-29, 1969.

Chase, J., Oceanographic observations along the east coast of the United States, Oceanogr. Rep. 38 (CG 373-38), p. 1, U.S. Coast and Geodetic Survey, Washington, D.C., 1971.

Costin, J. M., Gulf Stream transits south of Cape Hatteras, Gulf Stream, 4(9), 3-4, 1969.

Curtin, T. B., Ocean outfall waste water disposal feasibility and planning study: Oceanographic field observations off North Carolina, Summer survey 2-12 August 1977, Rep. 79-2, North Carolina State Univ., Raleigh, 1979a.

Curtin, T. B., Ocean outfall waste water disposal feasibility and planning study: Oceanographic field observations off North Carolina, Winter survey 2-12 February 1978, Rep. 79-3, North Carolina State Univ., Raleigh, $1979 b$.

Curtin, T. B., Ocean outfall waste water disposal feasibility and planning study: Oceanographic field observations off North Carolina, Spring survey 12-22 May 1978, Rep. 79-4, North Carolina State Univ., Raleigh, 1979c.

Curtin, T. B., Ocean outfall waste water disposal feasibility and planning study: Oceanographic field observations off North Carolina, Fall survey 1-11 November 1977, Rep. 79-5, North Carolina State Univ., Raleigh, 1979d.

Deschamps, J. R., L. P. Atkinson, J. J. Singer, W. S. Chandler, and T. N. Lee, Hydrographic observations in the Georgia Bigh (December 1976), Tech. Rep. 79-1, Georgia Mar. Sci. Center, Savannah, 1979.

DeRycke, R. J., and P. K. Rao, Eddies along a Gulf Stream boundary viewed from a Very High Resolution Radiometer, $J$. Phys. Oceanogr., 3, 490-492, 1973.

Düing, W., Synoptic studies of transients in the Florida Current, $J$. Mar. Res., 33, 53-73, 1975.

Ewing, J., M. Ewing, and R. Leyden, Seismic-Profiler Survey of Blake Plateau, Bull. Am. Assoc. Petrol. Geol., 50(9), 1948-1971, 1966.
Fuglister, F. C., Annual variations in current speeds in the Gulf Stream system, J. Mar. Res., 10, 119-127, 1951.

Fuglister, F. C., and A. D. Voorhis, A new method of tracking the Gulf Stream, Limnol. Oceanogr., 10, R115-R124, 1965.

Fuglister, F. C., and L. V. Worthington, Some results of a multiple ship survey of the Gulf Stream, Tellus, 3(1), 1-14, 1951.

Glibert, P. M., and T. C. Loder, Automated analysis of nutrients in seawater: a manual of techniques, Tech. Rep. 77-47, Woods Hole Oceanogr. Inst., Woods Hole, Mass., 1977.

Hazelworth, J. B., Oceanographic variations across the Gulf Stream off Charleston, South Carolina during 1965 and 1966, Tech. Rep. ERL 383-AOML 25, U.S. Dep. of Commerce, NOAA, 1976.

Iselin, C. O'D., A promising theory concerning the causes and results of long-period variations in the strength of the Gulf Stream System, Eos Trans. AGU, 19, 243-244, 1938.

Iselin, C. O'D., Preliminary report on long-period variations in the transport of the Gulf Stream system, Pap. Phys. Oceanogr. Meteorol., 8(1), 1-40, 1940.

Knauss, J. A., A note on the transport of the Gulf Stream, Deep Sea Res., 16, 117-123, 1969.

Lasley, S. R., L. P. Atkinson, J. J. Singer, and W. S. Chandler, Hydrographic observations in the Georgia Bight (April 1978), Tech. Rep. 79-5, Georgia Mar. Sci. Center, Savannah, 1979.

Lasley, S. R., L. P. Atkinson, J. J. Singer, and W. S. Chandler, Hydrographic observations in the Georgia Bight (April 1979), Tech. Rep. 81-1, Georgia Marine Sci. Center, Savannah, 1981.

Lee, T. N. L. P. Atkinson, and R. Legeckis, Observations of a Gulf Stream frontal eddy on the Georgia continental shelf, April 1977, Deep Sea Res., 28A(4), 347-378, 1981.

Legeckis, R. V., The influence of bottom topography on the path of the Gulf Stream at Latitude 31N from NOAA's satellite imagery Abstr., Eos Trans. AGU, 57(4), 260, 1976.

Legeckis, R. V., Satellite observations of the influence of bottom topography on the seaward deflection of the Gulf Stream off Charleston, South Carolina, J. Phys. Oceanogr., 9(3), 483-497, 1979.

Mathews, T. D., and O. Pashuk, A description of oceanographic conditions off the Southeastern United States during 1973, Tech. Rep. 19, South Carolina Mar. Res. Center, Charleston, 1977.

Maul, G. A., P. W. DeWitt, A. Yanaway, and S. R. Baig, Geostationary satellite observations of Gulf Stream meanders: Infrared measurements and time series analysis, J. Geophys. Res. 83(C12), 6123-6135, 1978.

Montgomery, R. B., Fluctuations in monthly mean sea level on eastern U. S. coast as related to dynamics of western North Atlantic Ocean, J. Mar. Res., 1(2), 165-185, 1938.

Niiler, P. P., and W. S. Richardson, Seasonal variability of the Florida Current. J. Mar. Res., 31(3), 144-167, 1973.

O'Malley, P. G., L. P. Atkinson, J. J. Singer, W. S. Chandler, and T. N. Lee, Hydrographic observations in the Georgia Bight (April 1977), Tech. Rep. 78-5, Georgia Mar. Sci. Center, Savannah, 1978

Pashinski, D. J., and G. A. Maul, Use of ocean temperatures while coasting between the Straits of Florida and Cape Hatteras, Mar. Weather Log, 17(1), 1-3, 1973.

Pierce, E. L., The chaetognatha over the continental shelf of North Carolina with attention to their relation to the hydrography of the area, J. Mar. Res., 12, 75-91, 1953.

Pietrafesa, L. J., Shelfbreak circulation, fronts and physical oceanography: East and west coast perspectives, in Shelf-Slope Bound ary: A Critical Interface on Continental Margins, edited by D. J. Stanley and G. J. Moore, Spec. Publ. 33, Society of Economic Paleontologists and Mineralogists, Tulsa, Okla., 1983.

Pietrafesa, L. J., J. O. Blanton, and L. P. Atkinson, Evidence for the deflection of the Gulf Stream at the Charleston Rise, Gulf Stream, 4(9), 3-7, 1978

Pietrafesa, L. J., and G. S. Janowitz, Dynamics of Carolina Capes and implications for sediment transport, paper presented Proceedings of 26th International Geological Congress, Paris, France, July 2-17, 1980 .

Pillsbury, J. E., The Gulf Stream: A description of methods employed in the investigation and the results of the research, report U.S. Coast and Geod. Surv. for 1890, Appendix 10, pp. 461-620, U.S. Government Printing Office, Washington, D.C., 1891.

Pratt, R. M., Bottom currents on the Blake Plateau, Deep Sea Res. 10, 245-249, 1963.

Pratt, R. M., The Gulf Stream as a graded river, Limnol. Oceanogr., 11, 60-67, 1966. 
Rao, P. K., A. E. Strong, and R. Koffler, Gulf Stream meanders and eddies as seen in satellite infrared imagery, J. Phys. Oceanogr., 2, 237-239, 1971.

Richardson, W. S., W. J. Schmitz, Jr., and P. P. Niiler, The velocity structure of the Florida current from the Straits of Florida to Cape Fear, Deep Sea Res., 16, (Suppl.), 225-231, 1969.

Rooney, D. M., G. S. Janowitz, and L. J. Pietrafesa, A simple model of deflection of the Gulf Stream by the Charleston rise, Gulf Stream, 4(11), 3-7, 1978.

Schmitz, W. J., Jr., and W. S. Richardson, On the transport of the Florida Current, Deep Sea Res., 15, 679-693, 1968.

Schroeder, E. H., North Atlantic temperatures at a depth of 200 meters, Serial atlas of the marine environment, Folio 2, American Geographical Society, New York, 1963.

Singer, J. J., L. P. Atkinson, W. S. Chandler, and S. S. Bishop, Hydrographic observations off Savannah and Brunswick, Georgia (March, May and September 1977 and January 1978), Tech. Rep. 80-1, Georgia Mar. Sci. Center, Savannah, 1980.

Stefánsson, U., L. P. Atkinson, and D. F. Bumpus, Hydrographic properties and circulation of the North Carolina shelf and slope waters, Deep Sea Res., 18, 383-420, 1971.

Strack, S. L., Surface temperature gradients as indicators of the position of the Gulf Stream, Tech. Rep. 53-53, Woods Hole Oceanogr. Inst., Woods Hole, Mass., 1953.
Strickland, J. D., and T. R. Parsons, A practical handbook of seawater analysis, Bull. Fish. Res. Bd Canada, 167, 1-310, 1972. Swallow, T. C., and L. V. Worthington, An observation of a deep countercurrent in the Western North Atlantic, Deep Sea Res., 8, $1-19,1961$.

Von Arx, W. S., D. F. Bumpus, and W. S. Richardson, On the finestructure of the Gulf Stream front, Deep Sea Res., 3, 46-65, 1955.

Vukovich, F. M., and B. W. Crissman, Some aspects of Gulf Stream western boundary eddies from satellite and in situ data, $J$. Phys. Oceanogr., 10, 1792-1813, 1980.

Weber, A. H., and J. O. Blanton, Monthly mean wind fields for the South Atlantic Bight, J. Phys. Oceanogr., 10(8), 1256-1263, 1980.

Yentsch, C., and D. W. Menzel, A method for the determination of phytoplankton chlorophyll and phaephytin by fluorescence, Deep Sea Res., 10, 221-231, 1963.

Yoder, J. A., L. P. Atkinson, T. N. Lee, H. H. Kim, and C. R. McClain, Role of Gulf Stream frontal eddies in forming phytoplankton patches on the outer southeastern shelf, Limnol. Oceanogr., 26, 1103-1110, 1981.

(Received April 1, 1982;

revised January 7, 1983;

accepted February 24, 1983.) 